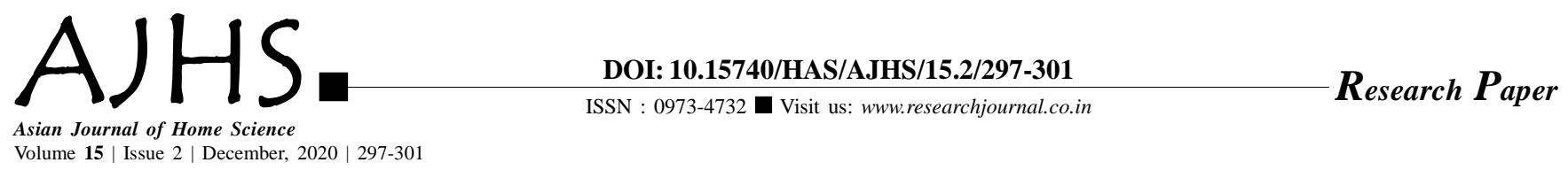

\title{
Evaluation of economics of a few green wastes used for income generation in Assam
}

\author{
Bijoylaxmi Bhuyan and Rumi Baruah
}

Received: 12.09.2020; Revised: 29.10.2020; Accepted: 19.11.2020

See end of the paper for authors' affiliations Bijoylaxmi Bhuyan Department of Family Resource Management and Consumer Science, College of Community Science, Assam Agricultural University, Jorhat (Assam) India Email : bijoylaxmi_b@rediffmail. com
ABSTRACT : There are varied kinds of plant-origin resources, many of which are considered wastes as these materials normally do not find proper economic utilization. Awareness on the utilization of the plant wastes in the household sector is the need of the hour for motivation and impact development among the target group. It can have a great impact on improvement of rural economy in a poor state like Assam. For example - with simple suitable technological intervention the areca palm leaf sheath can be utilized for making biosphere friendly disposable plates and bowls which are biodegradable and have a competitive market edge over paper and other non biodegradable plates made of synthetic materials. Many water bodies like canals, ponds, rivers etc. are choked by the explosive growth of aquatic weed called water hyacinth resulting in enormous direct loss. The prospect of making it an economically blessed weed by properly utilising it as business commodity is getting higher. The opportunity should be trapped by the local or indigenous people by developing adequate entrepreneurship with almost zero raw material cost. A study was under taken with the objectives: To assess the economics of areca palm sheath disposable serving plate making and Assessment of economics of use of water hyacinth for handicraft products. It was revealed that by using 231 numbers of palm leaf sheath per day and an 8 hours of working using two manually operated pressing machines and spending rupees 354 as daily additional cost, a person can earn a profit of rupees one lakh nineteen thousand nine hundred six annually, resulting in a benefit cost ratio of 2.23. On the other hand by making certain utility products using one kg of dried water hyacinth stems @ Rs.40/- one can earn an average of two thousand nine hundred fifty rupees weekly. The benefit cost ratio was found to be 1.65 which may increase further depending on products of finer quality. Availability of areca plantation and water hyacinth in this part of the country can thus be gainfully utilized as raw material for manufacturing eco- friendly useful biodegradable items with a high potential market face value and thus would help to enhance rural economy.

KEY WORDS: Economics, Green wastes, Income generation

- HOW TO CITE THIS PAPER : Bhuyan, Bijoylaxmi and Baruah, Rumi (2020). Evaluation of economics of a few green wastes used for income generation in Assam. Asian J. Home Sci., 15 (2) : 297-301, DOI: 10.15740/HAS/AJHS/15.2/297-301. Copyright@ 2020: Hind Agri-Horticultural Society. 